tinue to receive funding for automation projects.

While $65 \%$ of respondents at research universities reported the existence of an online catalog of part or all of the collection, only $23 \%$ at colleges so reported. While this finding is not a surprise, it demonstrates a strong opportunity for college libraries at this time. According to Richard Boss, who recently spoke to college librarians at the Oberlin Conference for College Librarians, the time is ripe for development of online catalogs. Much development by vendors in creating catalogs for larger libraries has placed such agents in a position to provide at this time integrated systems for smaller academic libraries. While costs are not trivial, the expectation of success is much greater than a few years ago.

\section{Conclusion}

The ACLS survey of scholars in relation to publishing, computers, and libraries provides implications for librarians both in research and in action. Such studies provide valuable material needed by librarians in order to direct them toward improved collections and service.

The authors are grateful to ACIS for providing us with useful insights about our relationships with one of our user communities and would welcome further dialogue on these issues.

\title{
William Wordsworth and
}

\section{the Age of English Romanticism}

\author{
By Linda G. Schulze \\ Assistant Director, Wordsworth Project \\ Rutgers University
}

\section{Rediscovering the Romantics.}

\footnotetext{
B eginning in November of 1987 , libraries across America will have the opportunity to join in a major humanities project that promises to have a lasting impact on the teaching of humanities in this country. The project, "William Wordsworth and the Age of English Romanticism," will provide a chance for people throughout the country to explore the topic of Romanticism from its 18thcentury roots to its 19 th-century triumphs, and implicitly invites the spectator to consider the 20th century's debt to the Romantics by making clear
}

the crucial role of Romanticism in shaping human thought.

Politically, historically, philosophically-the changes wrought during this era transformed the world and inevitably our conception of how we relate to it. The aim of this project, then, is to engender a reassessment of the role of Romanticism in the modern world: in high school and college curricula and, even more significantly, on the life of the individual and the culture as a whole.

Funded by a grant from the National Endow- 
ment for the Humanities and organized by Rutgers University-Newark and the Wordsworth Trust, Grasmere, England, the project has four interrelated elements. A museum exhibition, containing more than 300 manuscripts, paintings, books, watercolors, and other objects borrowed from almost one hundred museums, libraries, and private collections in England, France, and the United States, will be on display at the New York Public Library (Fall 1987), the Indiana University Art Museum (Winter 1988), and the Chicago Historical Society (Spring 1988). The exhibition will not only present an outstanding collection of cultural treasuresincluding paintings by such artists as William Blake, John Constable, John Sell Cotman, Thomas Girtin, Samuel Palmer, Francis Towne, and J.M.W. Turner; books, letters, and manuscripts by such writers as the Wordsworths and the Shelleys, Lord Byron, Samuel Taylor Coleridge, John Keats, Charles Lamb, Sir Walter Scott, and Mary Wollstonecraft; and other objects of historical and biographical interest. It will also provide a cohesive argument enumerating those ideas and forces which combined to create and to sustain the Romantic vision.

Many of these items have never been seen in this country before and may never be shown here again. The exhibition has been planned in conjunction with the Wordsworth Trust, and more than eighty treasures from Dove Cottage in Grasmere, once Wordsworth's home and now a museum, will be brought to the United States for the first - and probably the only-time. These treasures do not merely chronicle Wordsworth's life in the Lake District but the life of the age, illuminating the people and their world in an engaging and comprehensive way. Manuscripts, journals, and letters map out the literary and political revolutions occurring during that era, but also chart the psychological development of the individual in unsettled, often turbulent, times. Personal mementosWordsworth's spectacles and ice skates, locks of hair, sketches of family members-touchingly reveal and make real the private man behind the literary radical and add new dimensions to the landscape of the poetry.

Never before have so many of the central manuscripts, books, paintings, and watercolors of the Romantic period been gathered together in such richness and plenitude. Thus, at the climax to the exhibit, the central documents of the Romantic vision-Blake's Four Zoas, Coleridge's Kubla Khan, Keats's To Autumn, Byron's Childe Harold, and Shelley's Ode to the West Wind, plus of course, Wordsworth's The Prelude-will be displayed together, an astonishing tribute to the powers of the creative imagination.

So that this unique assembly of Romantic treasures and the impelling argument they convey will reach as large an audience as possible, a multiple copy poster panel exhibit based on the museum show, with twenty-four full-color poster panels per set, will be available to circulate through every state. These poster panel sets are at the heart of the entire project because they create an opportunity for a geographically wide and intellectually diverse audience, one not limited to the sites of the major museum exhibit but extended out into communities perhaps as isolated as the Lake District was in Wordsworth's time.

Displaying these sets in libraries, classrooms, public buildings, and other suitable places makes it possible to reach a much less traditional audience than would be likely to view a museum exhibition. Attractively designed and clearly written but certainly not simplistic or reductive, the poster panels invite attention and reward the reader, enabling the discovery of something elemental about the self and the world.

These poster panels will be widely available. Each State Humanities Council will have two sets to loan throughout the state, but additional sets can be purchased from the Wordsworth Project. The poster panels can be obtained either unmounted, for groups which have their own display systems, or mounted on easily assembled cardboard display kiosks. Also available for purchase from the Federation of State Humanities Councils is a travelling display system for mounting this and similar exhibits.

Along with these two exhibitions will be series of wide-ranging public programs centered around the theme of Romanticism-lectures, poetry readings, teacher's workshops, conferences, musical and dramatic performances-which, taken all together, should produce a dazzling year of Romanticism. The possibilities for public programming are limited only by the imagination of the programmer. Several programs are already being organized in cities throughout the country: many academics are planning campus-wide celebrations of Romanticism, and many local groups-literary, theatrical, and musical organizations, ethnic and historical organizations, even garden clubs-are joining in with plans for related projects.

Most libraries could run complementary exhibits, displaying objects from their collections that relate to any of the myriad aspects of Romanticism. The museum and poster panel exhibitions will explore six crucial Romantic subjects: the age of revolutions, Wordsworth's contemporaries, the changing view of childhood, the discovery of nature, simplicity and the commonplace, and memory, imagination and the sublime. Clearly, no one of these themes could be exhausted by a single exhibit, and, of course, the programs need not be limited to English Romanticism alone-many libraries and museums house rich treasures of American and European Romanticism in their collections.

The Age of Romanticism was a period of tremendous vitality, curiosity, spirit, and diversity, and the people whose lives define and illustrate this era are still of immense interest today. To examine the life of even one of the minor figures leads inevitably 


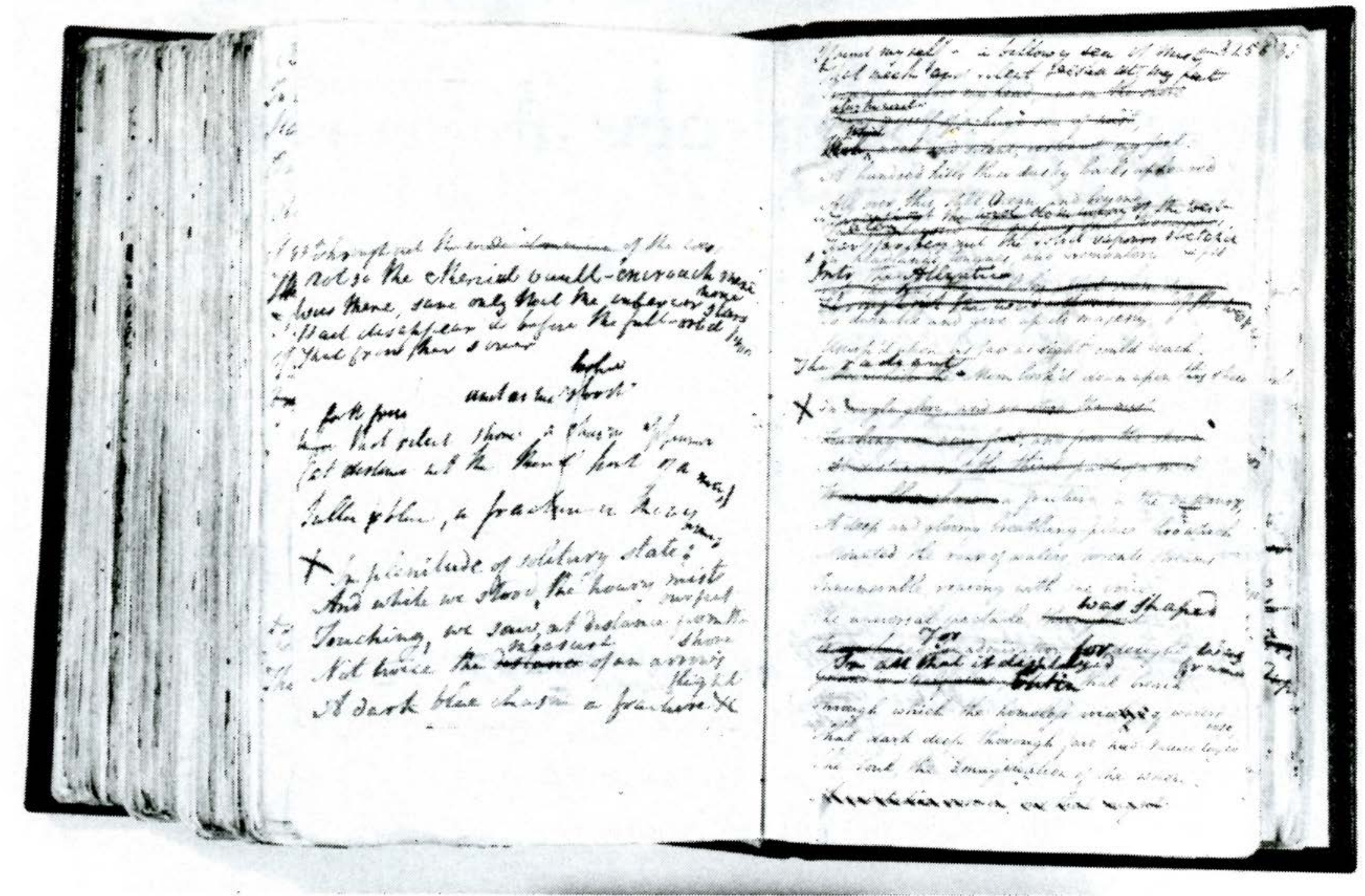

MS. A, DC MS. 52, p. 324v + 325r, manuscript book, William Wordsworth, "The Ascent of Snowdon" passage, The Prelude, from The Wordsworth Trust, Dove Cottage, Grasmere, England.

to all the major issues and movements of the day and generates questions about the entire age. In the same way, the wide variety of public programs, all separate yet connected, can generate questions about this modern world. The inevitable recognition of the complicated network of connections binding the modern viewer to the Romantics leads to the exploration of those specific shared beliefs and issues which still affect the thoughts and actions of man today, replicating, in a way, the questing and catholic spirit of that age.

Finally, to supplement the first three components of the project, short videos and various publications will be on hand-brochures, a book/cata$\log$ of the exhibition with over 100 color reproductions, a collection of essays on Romanticism, a teacher's guide-all meant to enrich the overall experience of "William Wordsworth and the Age of English Romanticism." The brochures, for example, will be available along with the poster panels, as a companion to that exhibit, enlarging upon its arguments and supplementing the text. The other publications and the videos will all address the subject of Wordsworth and Romanticism from various perspectives, each focusing in a different way on the man and his times.

The project will only succeed to the extent that the imagination of the audience is seized by the beauty and contemporaneity of these artists, writers and thinkers, and excited by the connections that emerge between the Romantics and modern thought.

All aspects of this project are envisioned as working together to transform potentially passive museum audiences into participating spectators who will consider those questions posed by the Romantics, and who, like the Romantics, can enter into and be held enthralled by such ideas as liberty, fraternity, and the essential dignity of man. It need not take large sums of money to plan a successful exhibit or program; most libraries will already have the resources on hand to put an interesting project together. But the timing is essential. In 1987-88 there should be renewed interest and understanding of Romanticism in this country. Librarians are capable of making a unique contribution to this project and should begin now to think about participating in this nationwide effort whose subject, as defined by Wordsworth in his "Prospectus" to The Excursion, is nothing less than "Man ...Nature, and...Human Life."

If you have any questions or would like any more information about this national project or about planning an exhibit or program, contact your State Humanities Council or the Wordsworth Project, English Department, Rutgers University, Newark, NJ 07102: (201) 648-5820.

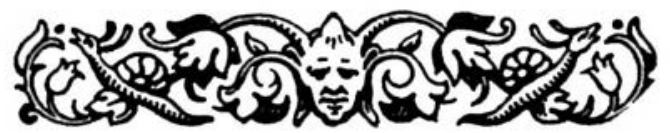

